\title{
A Note on Names
}

As is true with so many histories of central, eastern, and southeastern Europe, most of the personal names and places in this book have multiple versions that coexisted in the time period under study and were determined mostly by the language one spoke. For personal names, I have opted to use the one most commonly found in the documents consulted. So, for example, when referencing the 66-year-old head of the tobacco factory, I use the Germanized version of his name, Koloman Termatsits (which he used when engaging with local administrations), instead of the Hungarian version, Kálmán Termatsits (which he used when writing to his superiors in Budapest). For place names, I have chosen to use the version that would help a reader find the location on an English-language map today: so Vienna instead of Wien, Venice instead of Venezia, Istanbul instead of Constantinople, Opatija instead of Abbazia, Zadar instead of Zara, Split instead of Spalato, and so on.

The one exception is the name for the city the book focuses on: Fiume, which today is known as Rijeka. Fiume and Rijeka mean "river," in Italian and Croatian, respectively. For centuries, people called the town by either name. I use Fiume for historical reasons, not nationalist ones. Early twentieth-century Fiume does not delimit the same city as today's Rijeka. The Fiume in this book is the semiautonomous city-state and the suburbs it controlled; its official name was "Fiume," as Italian was one of the official languages, while Croatian was not. Today's Rijeka includes this urban space as well as others that in the early twentieth century were administered by different states using different official 
languages and different laws, such as Sušak and Kantrida. During the period covered by the book, Sušak was a separate town administered by Croatia-Slavonia, and Kantrida was a sleepy seaside village administered by the Austrian half of the Habsburg Empire. Fiume was its own city, administered by a mixture of self-made statutes and laws issued by the Hungarian Kingdom of which it was part. To understand the hows and whys of the Fiume Crisis, it is crucial to respect these structural differences of the past. Hence the use of the name Fiume for the period under study. When discussing today's city, I call it Rijeka.

The reader will notice very quickly that wherever possible I have indicated the age and profession of every person named in the book, from the rebellious schoolchild, to the lowliest housecleaner, anxious baker, resourceful housewife, desperate retired dockworker, to the head of Fiume's provisional government. I did this intentionally to show how this history affected all age groups and every economic class, not just the veterans and young paramilitary men who have peopled most of the new histories of Europe's immediate postwar.

One last note on a naming choice that may perhaps seem odd. I use "the Kingdom of Serbs, Croats, and Slovenes" and the adjective SerbCroat-Slovene instead of the more commonly used (and less awkward) terms Yugoslavia and Yugoslav. The country formed in I9I8, which included most of what is today Slovenia, Croatia, Bosnia-Herzegovina, Serbia, Montenegro, Kosovo, and Macedonia, was not officially called Yugoslavia until I929, though the name was used in unofficial communications. That is not the primary reason for my choice. The real reason is that between I9I8 and I92I the issue of how the Kingdom of Serbs, Croats, and Slovenes would be organized, how centralized it would be, and what sort of state or national identity it would have was hotly contested over issues of post-imperial dissolution and post-WWI statemaking. The kingdom itself did not get a constitution until I92I, did not have a single currency until I923, and did not have its own citizenship law until I928. I use the official name instead of the unofficial one to acknowledge this context, even though it leads to some awkward moments. I use Yugoslav and Yugoslavia when they are specifically referenced in primary sources or when I am discussing the unitarian "Yugoslav" national political or cultural ideology. 